\title{
STUDY ON USE OF FUNDS RURAL PRIORITY FOR RURAL DEVELOPMENT IN ORDER TO ACHIEVE VILLAGE AUTONOMY
}

\author{
Sri Kusriyah \\ Sultan Agung Islamic University Semarang \\ s.kusriyah16@gmail.com
}

\begin{abstract}
The government policy in terms of rural development are set to determine the priority of the village budget is used for rural development initially was referring to Act No. 6 of 2014 on the village, Article 1 point 8 states that Rural Development is an effort to improve the quality of life and life to sebesar- the welfare of the village community. Priority use of the Village Fund to finance the implementation of priority programs and activities that cut across the field. among other areas of activity featured products village or rural areas
\end{abstract}

Keywords : Research Priorities, Rural Development, Rural Autonomy.

\section{A. INTRODUCTION}

Unitary state of Indonesia by the State Constitution RI 1945 is a state welfare laws this can be seen in Article 1 (3) Jo Article 34, principles of democracy, the Indonesian economy is based on the value of social justice. ${ }^{1}$ Indonesia is a state of law based on Pancasila and the Constitution of the Republic of Indonesia of 1945 to uphold moral values, ethics, morals and noble personality of the nation, faith and fear of God Almighty, and respect diversity in society, ${ }^{2}$ then all laws issued by the state as a means to achieve national goals Indonesia as stated in the preamble NRI 1945, paragraph four. The concept of a welfare state Pancasila State or Government is obliged to organize and direct the community as a whole or the family. ${ }^{3}$ One of the efforts to realize the goal of advancing the country, especially in terms of the general welfare, Article 34 of the Constitution of the Republic of Indonesia of 1945 provides a mandate for the host country as follows:

1) Destitute and neglected children who are maintained by the state,

${ }^{1}$ I Gusti Ayu Ketut Rachmi Handayani et al., Relationship between Energy Consumption in International Market and Indonesia Prices Regulation, International Journal of Energy Economics and Policy, no. 5 (2017): 9-15.

${ }^{2}$ Andri Winjaya Laksana and Suratman, Analisis Yuridis Penyidikan Tindak Pidana Pornografi Di Era Digitalisasi, Jurnal Pembaharuan Hukum I, no. 2 (2014): 169-77.

${ }^{3}$ Anis Mashdurohatun, 2016, Mengembangkan Fungsi Sosial Hak Cipta Indonesia: Suatu Studi Pada Karya Cipta Buku, 1st ed. UNS Press, Surakarta, p.4. 
2) The state develops social security system for all citizens and to empower the weak who can not afford accordance with human dignity,

3) The State is responsible for the provision of health care facilities and public services eligible fasilititas,

4) Further provisions on the implementation of these provisions stipulated in the legislation.

The village as the organizer of the state power of the lowest have an obligation to mewejudkan national goal that, tertutama related to the order of Article 34 paragraph (2) as described above, and therefore a wide range of regulations on village government has been issued by the country associated with the role of village government improving people's welfare. The existence of the village administration stipulated in Act No. 23 of 2014 on Regional Government administration Article 371 as amended by Act No. 9 2015. Article 2 states:

1. Unitary state of Indonesia is divided into the provinces and the provinces are divided into districts and municipalities,

2. Regencies and cities divided into districts and sub-districts are divided into urban and / or rural.

By RH Unang village Soenardjo ${ }^{4}$ is the unity of society based on customary and traditional laws that settle in a territory specific boundaries, ties outwardly and inwardly very strong, both because of heredity, have a vested interest, political, economic, social and security, has a board of management is selected, having wealth in a certain amount and the right to conduct its own domestic affairs. Understanding the village is also contained in the Act No. 6 of 2014 on the village of Article 1 paragraph 1 mentions the village and the traditional village or called by any other name hereinafter called the village is the unity of the legal community who have boundaries that are authorized to regulate and manage the interests of the local community by community initiatives,

The objective of the village administration is in accordance with Article 4 of Act No. 6 of 2014 aims village setting:

\footnotetext{
${ }^{4}$ Agus Sudrajat dalam LD Mirfan Zaeland, 2016, Analisis Yuridis Pengelolaan Keuangan Desa Berdasarkan Undang-undang Nomor 6 tahun 2014 (studi di Desa Bangkali Barat, Kecamatan Watopule Kabupaten Muna), Skripsi, p. 22. 
a. Give recognition and respect for the existing village with diversity before and after the formation of the Republic of Indonesia;

b. Providing clarity and legal certainty on the status of the village in the constitutional system of the Republic of Indonesia in order to realize justice for all Indonesian people;

c. Preserve and promote the customs, traditions, and culture of the village;

d. Encourage innovation, movement, and the participation of the village community to the development potential and assets together for the welfare of the village;

e. Village Government formed a professional, efficient and effective, transparent and accountable;

f. Improve public services for the people of the village in order to accelerate the realization the general welfare;

g. Increasing the resilience of social culture in order to realize the villagers of the village that is capable of maintaining social cohesion as part of national security;

h. Promote the economy of the villagers as well as address the disparity of national development;

i. Strengthening the village community as a subject of development.

In an effort to realize the objectives of the village administration, which is part of the national goals village government has the authority under Article 18 Authority of the Village include the authority in the field of organizing village administration, the implementation of Rural Development, fostering community village, and community empowerment village based community initiatives, the right of origin origin, and customs of the village, Article 19 stipulates that the authority of the village include:

a. authorized under the right origin;

b. Village-scale local authority;

c. authority assigned by the Government, Provincial Government, or the Government of Regency / City; and

d. other powers assigned by the Government, Provincial Government, or the Government of Regency / City in accordance with the provisions of the legislation.

The exercise of authority by right of origin and local authority scale village is set and maintained by the village, the exercise of authority assigned and the exercise of authority 
other tasks of the Government, Provincial Government, or the Government of Regency / City taken care of by the village, the assignment of the Government and / or Government the village area includes the implementation of the Government to the village, the implementation of Rural Development, Rural community development and empowerment of village communities. Assignment referred to with the cost.

To run the village government authority should have used financial funding programs for village government. In Article 71 set:

a) Rural finance is all rights and obligations of the village which can be valued in money and everything in the form of money and goods related to the implementation of the rights and obligations of the village.

b) Rights and obligations referred to in paragraph (1) generate revenue, expenditure, financing and financial management of the village.

Article 72 (1) Income derived from the village:

a. Village revenues consist of net income, on assets, self-help and participation, mutual effort, and others revenues Village;

b. the allocation of the State Budget;

c. That part of the local taxes and levies Regency / City;

d. The village fund allocation that is part of the balance of funds received by the district / city;

e. Financial assistance from the Budget of the Provincial and Budget of the Regency / City;

f. Grants and donations that are not binding on third parties; and

g. Village other legitimate income.

From the financial resources of the village mentioned above, among others mentioned is the village fund which according to the Regulation of the Minister of Rural, Rural Development and Transmigration Republic of Indonesia Number 19 of 2017 on Priority Setting Use Village Fund 2018, Article 1 paragraph 2, states that the village fund is a fund sourced of budget revenues and expenditures that are intended for the village that is transferred through income and expenditure budgets of the district / city and used for the execution of development, social development and community empowerment. Article 1 paragraph 8 states that rural development is improving the quality of life and life to the 
maximum villagers. Based on this background, the authors draw the formulation of the problem, namely:

1. How can government policy in determining budget priorities village funds intended for rural development

2. How can rural development policy in realizing village autonomy.

\section{B. RESULT AND DISCUSSION}

\section{Government Policy Determine Budget Priorities In The Village Fund Intended For Rural Development}

National development is a series of sustainable development efforts that encompass all aspects of society, the nation and the state, to carry out the task of realizing national goals as defined in the Preamble of the Constitution of the Republic of Indonesia Of 1945. The series of such development efforts will contain activities which unabated development, by raising the level of social welfare of generations. Implementation was carried out in the context of efforts to meet the needs of the present without compromising the ability of future generations to meet their needs. ${ }^{5}$

Public policy is any decision made by the political system of the State, provincial, district and village or RW and RT, agencies / institutions / organs supra countries such as ASEAN, the United Nations, also including the political system, each of these systems make public policy for the public each and for the system to collect and mobilize public resources are concerned. ${ }^{6}$ Therefore, the public policy implications as follows: ${ }^{7}$

a. Public policies that shape originally was a stipulation of government actions,

b. Public policy is not enough just expressed in formal texts, but also to be carried out or implemented in practice,

c. The public policy in effect must have a purpose and a goal ?? impacts, both long term and short term, which has been carefully contemplated beforehand,

5 General Explanation of Act No. 17 of 2007.

6 Samodra Wibawa, 2011, Politik Perumusan Kebijakan Publik, Graha Ilmu, Yogyakarta, p.3.

7 Ibid, p.28. 
d. In the end all of the above process is intended for the fulfillment of public interest.

Based on the above public policy is basically a means of fulfilling the needs or interests of the community, meaning the size of the success or failure of public policy depends on how the public rate, if people feel the needs and interests are met by public policy, then by itself public policy was considered to have to function successfully. Referring to the concept of good governance, public policy it considers that there is no election internal processes of public policy on the one hand, the dynamics of the community on the other hand, it means starting from the formulation of public policy until the evaluation of all the elements that exist in the community should be involved, not A participatory manner, but also emancipatory. ${ }^{8}$

The purpose of the priority use of village funds provided for in Article2 that the determination of priorities for the use of the Village Fund aims to:

1. Provide a reference for the rights of the authority of origin and village scale local authority financed by the Village Fund in implementing programs and activities;

2. Provide a reference for the Government of Regency / City in preparing the technical guidelines of the Dana village; and

3. Provide a reference for the Local Government Center in the monitoring and evaluation of the use of the Village Fund.

Prioritization of the use of the Village Fund is based on the following principles:

1. Justice, with emphasis on the rights and interests of all residents of the village without any discrimination;

2. Priority needs, to put the interests of the village is more urgent, more necessary and directly related to the interests of most of the villagers;

3. The village authority, with emphasis on the authority of origin rights and villagescale local authority;

4. Participatory, with emphasis on community initiative and creativity;

5. Resource-based self-management and execution priority independently village by village utilization of natural resources, giving priority to energy, thoughts and skills of village residents and local knowledge; and

8 T.Saiful Bahri, et al, 2004, Hukum Dan Kebijakan publik, YPAPI, Yogyakarta, p.29. 
6. The village typology, considering the circumstances and the fact geographical characteristics, sociological, anthropological, economic, and ecological village is typical, and changes or developments and progress of the village.

\section{Rural Development in the Context realize Village Autonomy}

Autonomy is the essence of governance with a decentralized system, derived from the ancient Greek word autos (alone), nomos (laws) ${ }^{9}$, The right to selfgovernment as the joint democratic unity in a country other not mean autonomy, ie the right to manage her own household. ${ }^{10}$ Autonomy IS ALSO chosen Because, According to Jie Ma, Autonomy is a kind of governance mechanism with low cost and high profits. ${ }^{11}$ In contrast, According to Zibani Maundeni (et.all) ${ }^{12}$ stated that the centralization of power and the political inflexibility prevented that regional autonomy within countries leads to internal radical nationalism within the countries and to calls for separation the resulting in violent confrontations. The result of centralization is that regional autonomy was suppressed, and the distribution of resources and marginalized communities benefited some others.

In Act No. 23 of 2014 Article 1 (6) of regional autonomy is the rights, powers and obligations of the autonomous regions to set up and manage their own affairs and interests of local communities in the system of the Republic of Indonesia. In the structure of the Indonesian state administration in addition there is an autonomous region under Act No. 6 of 2014 there is the governance structure of the lowest socalled village, which meant the village and the traditional village or called by any other name hereinafter called the village is the unity of the legal community who have boundaries that are authorized to organize and manage the interests of the local community by community initiatives, the right of the origin and / or customary rights recognized and respected in government system unitary state of Indonesia.

9 Nomensen Sinamo, 2010, Perbandingan Hukum Tata Negara, Jala Permata Aksara, Jakarta, p.34.

10 Ni'matul Huda, 2014, Hukum Tata Negara Indonsia, Edisi Revisi, Jakarta, Radjagrafindo Persada, p.307.

${ }^{11}$ Jie Ma, Autonomy Replacing Heteronomy: Transfer of Management Model of Urban Community, dalam Asian Social Science Vol. 6, No. 11; November 2010, ISSN 1911-2017 E-ISSN 1911-2025 p. 142, accessed on 6 September 2017.

12 Zibani Maundeni (et.all), The Rise of Barotse Separatist Nationalism in Zambia: Can Its Associated Violence Be Prevented?, dalam Journal of Politics and Law; Vol. 8, No. 4; 2015 ISSN 1913-9047 E-ISSN 1913-9055 Published by Canadian Center of Science and Education, p. 264, accessed on 6 September 2017. 
Based on the meaning of the village above shows the village is an autonomous village whose autonomy is derived from the right to the origin and / traditional rights, so different from the autonomous regions autonomous rights derived from the application of the principle esentralisasi. as an autonomous village under Act No. 6 of 2014 on the village of Article 18 states that the authority of the village include the authority in the field of organizing village administration, the implementation of Rural Development, fostering community village, and community empowerment village based community initiatives, the right of origin, and customs of the village. include:

a) Authorized under the right origin;

b) Village-scale local authority;

c) Authority assigned by the Government, Provincial Government, or the Government of Regency / City; and

d) Other powers assigned by the Government, Provincial Government, or the Government of Regency / City in accordance with the provisions of the legislation.

Under the provisions of Act No. 6 of 2014 mentioned above, in Determination of Use Village Village Fund discretion to regulate and manage the affairs of the authority of the village bounded by the origin and the right scale local authority Village. Procedures for establishing the authority of the village is regulated under Government Regulation No. 43 Of 2014 concerning the Implementation Regulations of Act No. 6 of 2014 on the Village as amended by Government Regulation No. 47 Of 2015 on the Amendment of Government Regulation No. 43 Of 2014 concerning the Implementation Regulations Act No. 62014 about the village in particular in Article 37. The procedure for the determination of the authority of the village are as follows: ${ }^{13}$

a. District / City Government to implement

1. Local government district / city to identify and inventory the authority based on the right of the origin and scale local authority by involving village Village;

2. Based on identification and inventory of the village authority, regents / mayors establish rules regent / mayor on the list of the authority based on the rights

13 Enclosure Regulation the Minister village, Rural Development of Disadvantaged and Transmigration No. 19 2017 
of origin and village scale local authority in accordance with the legislation; and

3. Regulation regent / mayor is followed by the village government to establish regulations regarding the authority under the right village origins and villagescale local authority in accordance with the circumstances, conditions and local needs.

b. The activities financed by the Rural Fund should be based on the authority of the village that have been defined with village regulations. Therefore, the activities funded by the Village Fund shall be included in the list of the authority of the village. Thus, the village authority to make regulations governing the use of village Village Fund to finance activities in the village.

Affairs and activities that are prioritized in rural development in the implementation of village authority is as follows: ${ }^{14}$

1. Use Priority Setting mandate Village Fund.

Legislation that is higher than the Village Regulations relating to use of the Village Fund is Government Regulation No. 60 of 2014 on Village Fund Originating from the Budget of the State, as amended several times, the latest by Government Regulation No. 8 of 2016 regarding the Second Amendment to the Regulation government No. 60 of 2014 on Village Fund Originating from the Budget of the State which states that under Article 19 paragraph (1) provides that the Village Fund used to finance governance, development, community empowerment, and community and in Article 19 paragraph (2) stipulates that priority Village Fund to finance the development and empowerment. Therefore,

2. Priority Activity Field of Rural Development

Village Act mandates that the purpose of development is to improve the welfare of society Rural Villages and the quality of human life and reduce poverty through the fulfillment of basic needs, the development of village infrastructure, local economic development potential, as well as the use of natural resources and environmentally sustainable manner. Rural development activities that can be funded Village Fund is as follows: 
a. Procurement, construction, development and maintenance of infrastructure the village

1. Procurement, construction, development and maintenance of facilities and infrastructure of the neighborhood, among others:

a. development and / or improvement of a healthy home for the poor;

b. lighting neighborhood;

c. pedestrian;

d. drainage;

e. gutters;

f. garbage dump;

g. wheelie bin;

h. waste transporter vehicle;

i. waste processing machine; and

j. Other residential neighborhood infrastructure facilities in accordance with the authority of the village and decided in consultation Village.

2. Procurement, construction, development and maintenance of transportation infrastructure, among others:

a. mooring boats;

b. residential street;

c. Rural road axis;

d. Rural roads between settlements to rural areas;

e. Rural roads between settlements into tourist sites;

f. The village bridge;

g. water tunnel;

h. Village terminal; and

i. other transportation infrastructure in accordance with the authority of the village and decided in consultation Village.

3. Procurement, construction, development and maintenance of energy facilities and infrastructures, among others:
a. micro hydro power plant;
b. diesel power plants; 
c. solar power;

d. biogas installations;

e. electrical power distribution network; and

f. other energy infrastructure facilities in accordance with the authority of the village and decided in consultation Village.

4. Procurement, construction, use and maintenance of facilities and infrastructure for information and communication, among others:

a. Internet network for residents of the village;

b. Village website;

C. equipment loudspeakers (loudspeaker);

d. payphone;

e. Radio Single Side Band (SSB); and

f. other communications infrastructure in accordance with the authority of the village and decided in consultation Village.

b. Improving Quality and Access to Basic Social Services

1. Procurement, construction, development and maintenance of health infrastructure, among others:

a. Village-scale clean water;

b. environment sanitation;

c. the toilet building;

d. showers, sinks, toilet (MCK);

e. car / boat for ambulance Village;

f. tools with disabilities;

g. rehab with disabilities;

h. clinics;

i. posyandu;

j. poskesdes / polindes;

k. Posbindu;

I. rapid test reagent kid to test samples of food; and

m. other health infrastructures in accordance with the authority of the village and decided in consultation Village. 
2. Procurement, construction, development and maintenance of infrastructure of education and culture, among others:
a. public reading;
b. Early Childhood Education building;
c. books and learning equipment Aanak Early Childhood Education other;
d. The child rides Aanak Early Childhood Education;
e. garden religious study;
f. The village library building;
g. book / literature;
h. training hall / community learning;
i. art Gallery;
j. documentary film;
k. art equipment; and
I. educational and cultural infrastructure more in accordance with the authority of the village and decided in consultation Village

c. Procurement, construction, development and maintenance of infrastructure the village economic ventures

1. Procurement, construction, development and maintenance of infrastructure facilities of agricultural production for food security efforts and large-scale agricultural enterprises productive, focused on the formation and development of the village featured products and / or featured products of rural areas, among others:
a. small-scale dams;
b. construction or repair dam;
c. The village irrigation;
d. printing of agricultural land;
e. fish pond;
f. fishing vessels;
g. landing place of fishing vessels;
h. salt ponds;
i. cattle pen; 
j. animal feed machinery;

k. storage warehouse of agricultural inputs (saprotan); and

I. Other agricultural production infrastructure in accordance with the authority of the village and decided in consultation Village.

2. Procurement, construction, use and maintenance of facilities and infrastructure for processing of agricultural products for food security and agricultural businesses are focused on the formation and development of the village featured products and / or featured products of rural areas, among others:

a. drying of agricultural products such as grain drying floors, corn, coffee, cocoa, copra, and the drying of fish;

b. The village barns;

C. cold storage (cold storage); and

d. infrastructure other agricultural processing in accordance with the authority of the village and decided in consultation Village.

\section{CLOSING}

\section{Conclusion}

1. In the framework of rural development by the government through the Minister of Rural, Rural Development of Disadvantaged And Transmigration issued Regulation No. 19 of 2017 on Priority Setting Use Village Fund 2018, that the policy priorities for the use village funds according to the rules set out in Article 4 prioritized for:

a. Priority use of the Village Fund to finance the implementation of programs and activities in the field of building the village and the village community empowerment.

Priority use of the Village Fund to finance the implementation of priority programs and activities that cut across the field. among other areas of activity featured products of village or rural area, village or BUM BUM Village Commons, ponds and village sports facilities in accordance with the authority of the village. The construction of sports facilities Village is a business unit managed by the village or BUM BUM Village Commons. Priority use of the Village Fund shall be published by 
the village government to the village community in a public space that people can access the village.

2. That the Rural Development financed by the Village is in order to realize the autonomy of the village which is based on the provisions of Act No. 6 of 2014 that in determining the use of funds village by village authority to regulate and manage limited to the affairs of village authority by right of origin and local authority scale village, Procedures for establishing the authority of the village is regulated under Government Regulation No. 43 Of 2014 concerning the Implementation Regulations of Act No. 6 of 2014 on the Village as amended by Government Regulation No. 47 Of 2015 on the Amendment of Government Regulation No. 43 Of 2014 concerning the Implementation Regulations Act Act No. 6 of 2014 on the village, especially in Article 37. the procedure for the determination of the authority of the village are as follows:

a. Local government district / city to identify and inventory the authority based on the right of the origin and scale local authority by involving village Village;

b. Based on identification and inventory of the village authority, regents / mayors establish rules regent / mayor on the list of the authority based on the rights of origin and village scale local authority in accordance with the legislation; and

c. Regulation regent / mayor is followed by the village government to establish regulations regarding the authority under the right village origins and villagescale local authority in accordance with the circumstances, conditions and local needs.

d. The activities financed by the Rural Fund should be based on the authority of the village that have been defined with village regulations. Therefore, the activities funded by the Village Fund shall be included in the list of the authority of the village. Thus, the village authority to make regulations governing the use of village Village Fund to finance activities in the village. 


\section{BIBLIOGRAPHY}

Agus Sudrajat dalam LD Mirfan Zaeland, 2016, Analisis Yuridis Pengelolaan Keuangan Desa Berdasarkan Undang-undang Nomor 6 tahun 2014 (studi di Desa Bangkali Barat, Kecamatan Watopule Kabupaten Muna), Skripsi

Handayani, I Gusti Ayu Ketut Rachmi, Edi As'Adi, Guntur Hamzah, Tommy Leonard, and Gunarto. "Relationship between Energy Consumption in International Market and Indonesia Prices Regulation." International Journal of Energy Economics and Policy 7, no. 5 (2017): 9-15.

Jie Ma, "Autonomy Replacing Heteronomy: Transfer of Management Model of Urban Community", dalam Asian Social Science Vol. 6, No. 11; November 2010, ISSN 1911-2017 E-ISSN 1911-2025 hal. 142, accessed on 6 September 2017.

Laksana, Andri Winjaya, and Suratman. "Analisis Yuridis Penyidikan Tindak Pidana Pornografi Di Era Digitalisasi." Jurnal Pembaharuan Hukum I, no. 2 (2014): 169-77.

Mashdurohatun, Anis. Mengembangkan Fungsi Sosial Hak Cipta Indonesia: Suatu Studi Pada Karya Cipta Buku. 1st ed. Surakarta: UNS Press, 2016.

Ni'matul Huda, 2014, Hukum Tata Negara Indonsia, Edisi Revisi, , Radjagrafindo Persada, Jakarta;

Nomensen Sinamo, 2010, Perbandingan Hukum Tata Negara, Jala Permata Aksara, Jakarta

Samodra Wibawa, 2011, Politik Perumusan Kebijakan Publik, Graha Ilmu, Yogyakarta.

T.Saiful Bahri, et al, 2004, Hukum Dan Kebijakan publik, YPAPI, Yogyakarta.

Zibani Maundeni (et.all), The Rise of Barotse Separatist Nationalism in Zambia: Can Its Associated Violence Be Prevented?, dalam Journal of Politics and Law; Vol. 8, No. 4; 2015 ISSN 1913-9047 E-ISSN 1913-9055 Published by Canadian Center of Science and Education, p. 264, accessed on 6 September 2017 